\title{
Quantification of mast cells and microflora in the vaginal cul-de-sac of the brushtail possum (Trichosurus vulpecula)
}

\author{
P. M. Mahoney ${ }^{1}$, P. R. Hurst ${ }^{1}$, B. J. McLeod ${ }^{1,3}$ and \\ M. A. McConnell ${ }^{2}$ \\ ${ }^{1}$ Department of Anatomy and Structural Biology, ${ }^{2}$ Department of Microbiology, University of \\ Otago, PO Box 56, Dunedin, New Zealand; and ${ }^{3}$ AgResearch, Invermay Agricultural Centre, \\ Private Bag 50034, Mosgiel, Dunedin, New Zealand
}

\begin{abstract}
Mast cells are typically associated with biological responses to intracellular parasitic or bacterial invasion in gut and pulmonary tissues. Large numbers of these cells are present in the vaginal cul-de-sac, a component of the reproductive tract in female brushtail possums (Trichosurus vulpecula). The presence of mast cells in this area may reflect microbial presence or indicate a role for mast cells in reproductive function in this marsupial. In this study, the number and spatial location of mast cells in vaginal cul-de-sac tissues at different reproductive stages was determined, and related to the presence of microflora. Vaginal cul-de-sac tissue was collected from juvenile $(n=5)$, lactationally anoestrous and cyclic adult brushtail possums ( $n=6$ per group). Oestrous cyclicity was induced by removal of pouch young and reproductive status was
\end{abstract}

confirmed by laparoscopy. Tissue was collected aseptically for microbiological procedures. The fractionator and optical disector stereological methods were used to quantify mast cell populations. In all groups, microflora

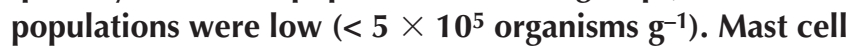
density in epithelial tissue was highest in lactationally anoestrous and luteal phase brushtail possums and lowest in follicular phase animals. No correlation between the numbers of bacteria isolated and mast cell density was apparent. Gram stained tissue showed no evidence of bacterial invasion. Mast cell density was significantly lower in epithelial tissue from follicular phase animals, corroborating previous studies in which an increase in mast cell degranulation coincided with high oestrogen concentrations.

\section{Introduction}

The vaginal cul-de-sac is a distinctive feature of the female reproductive tract in brushtail possums (Trichosurus vulpecula). It is a sac-like structure consisting of a median vaginal complex with two lateral canals which join inferiorly with the urethra to form a common urogenital sinus (Kean et al., 1964). Two uteri lie superior to the culde-sac with the cervices of each attached on either side of the median sagittal plane. The female brushtail possum is seasonally polyoestrous and monovular (Pilton and Sharman, 1962). There are numerous reports that the vaginal cul-desac complex increases in size with the onset of the breeding season and changes in size throughout the oestrous cycle to reach its maximum at oestrus (Tyndale-Biscoe, 1955; Crawford et al., 1997). These changes have been quantified histologically by light and electron microscopy (Crawford et al., 1999). The single layer of epithelial cells lining the vaginal cul-de-sac may undergo as much as a 17-fold increase in volume during the follicular phase. This hypertrophy is accompanied by the secretion of copious

*Correspondence.

Email: trish.mahoney@stonebow.otago.ac.nz amounts of mucus from the epithelial tissue into the lumen of the vaginal cul-de-sac. During the breeding season, the presence of suckling young suppresses the oestrous cycle and the vaginal cul-de-sac regresses (Crawford et al., 1997).

Mahoney et al. (2001a) reported the presence of a large number of mast cells in the luminal epithelium and underlying connective tissue of the vaginal cul-de-sac. The role of mast cells is generally considered to be associated with allergic reactions or microbial invasion, in which a phagocytotic (Abraham and Malaviya, 1997) or antigenpresenting (Malaviya et al., 1996) response is initiated. Consequently, mast cells are typically sited beneath epithelial surfaces or near to mucosal sites (Galli, 1993) where a response to parasitic invasion or environmental toxins can occur rapidly.

Mast cells were observed using electron and light microscopy in close association with epithelial cells in the vaginal cul-de-sac of brushtail possums, which might indicate a role for mast cells in tissue function (Crawford et al., 1999). Other studies have indicated a possible relationship between reproductive status and the number of mast cells in the rat (Jones et al., 1980) and hamster ovary (Krishna and Terranova, 1985; Krishna et al., 1986). Ferrando and Nalbandov (1968) reported a correlation between oestrogen exposure and histamine production by 
mast cells during uterine implantation in rats. It has also been hypothesized that histamine produced by uterine mast cells may be targeting myometrial smooth muscle cells and fibrous connective tissue elements, perhaps with a functional remodelling role of uterine tissue during the menstrual cycle and after parturition (Mori et al., 1997). In addition, the rat uterus has been found to respond in a contractile manner to immune challenges (for example, anti-rat $\lg \mathrm{E}$ ), through the activation of mast cells (Garfield et al., 2000). Studies on rat (Jones et al., 1994) and hamster ovary (Krishna and Terranova, 1985) identified an increase in mast cell degranulation when oestrogen concentrations are increased and it was suggested that the preovulatory $\mathrm{LH}$ surge may initiate this response (Krishna and Terranova, 1985; Krishna et al., 1986). Wilhelm et al. (2000) established that the number of mast cells and their activational state in the medial habendula of the brain in ring doves were both increased by exposure to the gonadal steroids, testosterone or dihydrotestosterone in the male and oestradiol in the female, implying a correlation between mast cell function and circulating steroid hormone concentrations.

The aim of the present study was to determine whether the presence of mast cells in the vaginal cul-de-sac of the brushtail possum is related to microbial invasion, and also to identify whether there are changes in the number of mast cells and their spatial location in association with changing reproductive status. To our knowledge, no previous studies have been conducted to identify the presence of microflora within the vaginal cul-de-sac of the brushtail possum or of other marsupials. Although there have been previous observations of mast cells in reproductive tissues, the estimation of their numbers has been by empirical counting methods (Gibbons and Chang, 1972; Jones et al., 1980; Mori et al., 1997). None of these studies have applied unbiased stereological methodology or calculated the total volume of tissue occupied by the cells, thereby providing a three-dimensional field for the estimation of total number and density of cells. In the present study, the number and location of mast cells was estimated by adopting a rigorous analysis of unbiased stereological methodology to estimate reference volume (Cavalieri, 1635) and to determine numerical density and total numbers of cells (Sterio, 1984).

\section{Materials and Methods}

\section{Animals}

All of the brushtail possums (Trichosurus vulpecula) used in the present study were captured live in the locality of Mosgiel, coastal Otago, New Zealand (latitude $45^{\circ} 53^{\prime} \mathrm{S}$ ). Before experimentation, the animals were housed in groups in the possum facility at AgResearch Invermay, and fed a diet of fresh fruit, bread and low $\mathrm{Ca}^{2+}$ cereal-based pellets with fresh water available ad libitum (McLeod et al., 1997).

The juvenile animals weighed between 0.70 and $1.5 \mathrm{~kg}$, and were estimated from measurements of head and crown-rump length to be 165-194 days of age (Lyne and Verhagen, 1957). Only adult animals weighing $>2.0 \mathrm{~kg}$ were selected (Crawford et al., 1997, 1998) to ensure that all female possums were reproductively mature.

All experimental procedures had prior approval from the AgResearch Invermay Animal Ethical Committee under the Animal Protection (Codes of Ethical Conduct) Regulations 1989.

\section{Experimental design}

Suckling pouch young were removed from eighteen adult female brushtail possums to induce oestrous cyclicity and ovulation (Pilton and Sharman, 1962). These animals were then either killed immediately (lactationally anoestrous group) or monitored by repeated laparoscopy (Crawford et al., 1997) to identify the late follicular phase (presence of a large (approximately $6 \mathrm{~mm}$ ) follicle) or luteal phase (presence of a corpus luteum, 9-12 days after ovulation) of the oestrous cycle ( $n=6$ per group). The pouch young were killed by i.p. injection of barbiturate (EuthalTM 1-2 ml; $170 \mathrm{mg}$ sodium pentobarbitone $\mathrm{ml}^{-1}$, $25 \mathrm{mg}$ sodium phenytoin $\mathrm{ml}^{-1}$; Delta Veterinary Laboratories Pty Ltd, Hornsby, New South Wales).

\section{Laparoscopy procedure}

Animals were anaesthetized by halothane inhalation (Fluothane; ICI New Zealand Ltd, Lower Hutt), and the gross anatomy of the reproductive organs viewed and assessed for vascularity and size by laparoscopy as described by Crawford et al. (1997).

\section{Tissue collection}

Animals were killed by an intracardiac injection of barbiturate (EuthalTM 4-8 ml) while under halothaneinduced anaesthesia. Animals were weighed and a mid-line and two lateral incisions were made in the abdominal wall to expose the reproductive tract. The status of the ovaries, uteri and vaginal cul-de-sac was recorded and samples of cul-de-sac luminal contents taken for microbiological studies, before the whole reproductive tract was aseptically recovered. The vaginal cul-de-sac was dissected free from the rest of the reproductive tract and weighed.

\section{Tissue collection for microbiology}

A small mid-line incision was made in the anterior wall of the vaginal cul-de-sac with sterile instruments. Three sterile samples of the vaginal cul-de-sac contents were then taken by inserting sterile cotton-tipped applicators through the incision. Two of these were placed in Carey Blair transport medium (Oxoid) and the third sample was used to make a microscopy smear. The sterile swabs were transported to the laboratory for plating and incubation. The $\mathrm{pH}$ of the luminal contents of the vaginal cul-de-sac was determined by inserting a $\mathrm{pH}$ indicator strip (Merck, D-6100 Darmstadt). 
Vaginal cul-de-sac tissue was also collected from a proportion of animals $(n=3$ for lactationally anoestrous, follicular and luteal groups, and $n=2$ for juvenile group), for further microbiological analysis. After aseptic removal, the vaginal cul-de-sac was divided into two by dissection in the mid-sagittal plane and placed in Carey Blair transport medium (Oxoid) for transport to the laboratory.

\section{Microbiological procedures}

Upon return to the laboratory, one of the swabs was placed immediately in an anaerobic glove-box (Forma Scientific, Marietta, $\mathrm{OH}$ ) and inoculated on to a prereduced tryptic soy agar (Difco Laboratories, Detroit, MI) plate containing 5\% sheep blood (Life Technologies, Penrose, Auckland) and also on to a pre-reduced brain heart infusion (BHI) agar (Difco) plate supplemented with $10 \%$ yeast-extract (Difco). The plates were then incubated at $37^{\circ} \mathrm{C}$ and examined each day for 7 days for signs of bacterial growth. All colonies that appeared were subcultured and Gram stained. Organisms from the sub-culture plates were stored at $-20^{\circ} \mathrm{C}$ in skimmed milk.

The second swab of each pair was used to inoculate a Rogosa agar (Difco) plate for isolation of lactobacilli, a Sabouraud agar (Difco) plate for yeasts and two tryptic soy agar (Difco) + 5\% sheep blood (Life Technologies) plates. The Rogosa plate was incubated at $37^{\circ} \mathrm{C}$ for 2 days; one blood agar plate was incubated at $37^{\circ} \mathrm{C}$ for 4 days in a $5 \%$ $\mathrm{CO}_{2}$ incubator. The Sabouraud plate was incubated at $30^{\circ} \mathrm{C}$ for 4 days and one blood agar plate was incubated aerobically at $37^{\circ} \mathrm{C}$ for 4 days. Representative organisms were stored at $-20^{\circ} \mathrm{C}$ in skimmed milk after sub-culture and Gram stain examination.

The smears made from the third swab were heat fixed, stained by the Gram method and examined under a microscope at $\times 100$ magnification using an oil immersion lens.

Depending on the mass of the vaginal cul-de-sac tissue recovered, either $\mathrm{BHI}$ was added to the whole piece of tissue in a homogenizer tube to give a 1:10 dilution $(\mathrm{w} / \mathrm{v})$ or $0.5 \mathrm{~g}$ of tissue was placed in a homogenizer tube and 1:10 dilution (w:v) made in BHI. Samples were homogenized and diluted in tenfold dilution steps to $10^{-3}$. Aliquots $(100 \mu \mathrm{l})$ of the $10^{-1}$ dilution were spread on to either Rogosa, Sabouraud, MacConkey or blood agar plates. In addition, $10 \mu \mathrm{l}$ of the $10^{-3}, 10^{-2}$ and $10^{-1}$ dilutions were plated to sectors of blood agar (3) and brain heart infusion plus yeast extract (BHIYE) plates. One blood agar and one BHIYE plate (which had been pre-reduced) were incubated in the glove-box at $37^{\circ} \mathrm{C}$ for $5-7$ days. One Rogosa plate and one blood agar plate were incubated in $5 \% \mathrm{CO}_{2}$ at $37^{\circ} \mathrm{C}$, and the Sabouraud plates at $30^{\circ} \mathrm{C}$. The remaining plates were incubated aerobically at $37^{\circ} \mathrm{C}$.

A smear of the homogenate was made on to a microscope slide, stained with Gram's stain and examined under a microscope.

\section{Tissue collection for stereological analysis and tissue Gram staining}

Vaginal cul-de-sac tissue was fixed in $4 \%(\mathrm{w} / \mathrm{v})$ paraformaldehyde in PBS for 18-24 h, and then fractionated into pieces of equal size (Gundersen et al., 1988), arranged linearly, and randomly systematically selected tissue blocks were embedded in Technovit (Technovit 7100; Kulzer and Co., Werheim). One block of vaginal culde-sac tissue from each animal was embedded in paraffin wax, and cut into sections of $4 \mu \mathrm{m}$ thickness (Leica Rotary Microtome 2050; Labsupply Pierce) for tissue Gram staining (Bancroft and Stevens, 1990).

Random systematic sampling (Gundersen and Jensen, 1987) was further applied to select blocks for sectioning. Sections were cut at $30 \mu \mathrm{m}$ thickness (Reichert Jung Leica 2050 Supercut; Cambridge Instrument GmbH, D-6907, Nussluch) and every tenth section was stained with Giemsa histological stain (Giemsa (Azur Eosin); George T. Gurr Ltd, London) and a No.1 coverslip was placed over the section.

\section{Stereological pilot study}

A pilot study was conducted to determine which sampling strategy best allowed for analysis of mast cell distribution within vaginal cul-de-sac tissue. Tissue was sampled using a combination of step sizes and speed controls, with various sized optical disector counting frames (Fig. 1). In many instances, the average number of cells per counting frame was either low or zero, or alternatively, cell aggregations were identified with most mast cells located either in the epithelium or in the connective tissue near to the epithelial-connective tissue boundary. Howard and Reed (1998) suggested that in instances of such heterogeneity of cell distribution, it may be more efficient to use numerous small disectors rather than a few large ones in the stereological analysis.

\section{Sampling regimen for the optical disector}

The following sampling rules, as adopted from those described by Howard and Reed (1998) were set: (i) at least 100 mast cells per animal were counted, (ii) at least $2-5$ mast cells could be captured in the counting frame and (iii) at least 100 counting frames were used for each animal.

Stereological analysis was undertaken on 2-10 sections from each of three blocks of the vaginal cul-de-sac tissue from each animal. Sections were projected on to a television screen covered by an unbiased counting frame (Gundersen, 1977) with dimensions of $240 \mathrm{~mm} \times 170 \mathrm{~mm}$, and moved by a step and speed control unit that accommodated the sampling rules outlined above. Mast cells were identified in both the epithelium and connective tissues (Fig. 1), and the component tissue noted. In instances in which the optical disector counting frame landed on a section of tissue composed of both epithelium and connective tissue, half the area of the disector was identified as epithelium and the other half as connective tissue. This 
Table 1. The numbers and range and classification of microorganisms cultured from luminal contents or tissue of the vaginal cul-de-sac of juvenile or adult female brushtail possums (Trichosurus vulpecula) that were either lactationally anoestrous or in the follicular or luteal phase of the oestrous cycle

\begin{tabular}{|c|c|c|c|c|c|c|}
\hline \multirow[b]{2}{*}{ Group } & \multirow[b]{2}{*}{$\mathrm{n}$} & \multirow[b]{2}{*}{$\begin{array}{l}\mathrm{pH} \\
\text { range }\end{array}$} & \multicolumn{2}{|c|}{ Luminal contents } & \multicolumn{2}{|c|}{ Tissue } \\
\hline & & & $\begin{array}{l}\text { Number of } \\
\text { colonies }\end{array}$ & $\begin{array}{l}\text { Gram stain } \\
\text { morphology } \\
\text { of colony types } \\
\text { isolated }\end{array}$ & $\begin{array}{c}\text { Number of colonies } \\
\text { [range] }\end{array}$ & $\begin{array}{l}\text { Gram }(\mathrm{G}) \text { stain } \\
\text { morphology } \\
\text { of colony types } \\
\text { isolated }\end{array}$ \\
\hline Juvenile & 5 & 8 & $\mathrm{Nil}(0 / 3)$ & & $\begin{array}{l}3.7 \times 10^{3} \\
{\left[<10^{3}-3.7 \times 10^{4}\right]} \\
(1 / 2) \\
\text { One colony type }\end{array}$ & $\mathrm{G}+$ rods \\
\hline Lactationally anoestrous & 6 & $7-8$ & $\begin{array}{l}8(1 / 3) \\
\text { Four colony types }\end{array}$ & $\begin{array}{l}1 \times G-\text { rods } \\
2 \times G+\text { cocci } \\
1 \times G+\text { rods }\end{array}$ & $\begin{array}{l}2.79 \times 10^{5} \\
{\left[5.0 \times 10^{3}-3.23 \times 10^{5}\right]} \\
(3 / 3) \\
\text { Four colony types }\end{array}$ & $\begin{array}{l}2 \times G-\text { rods } \\
1 \times G+\text { cocci } \\
1 \times G+\text { rods }\end{array}$ \\
\hline Follicular phase & 6 & $4-7$ & $\begin{array}{l}5(2 / 3) \\
\text { Two colony types }\end{array}$ & $\begin{array}{l}1 \times G+\text { rods } \\
1 \times G-\text { rods }\end{array}$ & $\begin{array}{l}4.3 \times 10^{3} \\
{\left[3.0 \times 10^{2}-1.06 \times 10^{4}\right]} \\
(3 / 3) \\
\text { Nine colony types }\end{array}$ & $\begin{array}{l}2 \times \mathrm{G}-\text { rods } \\
3 \times \mathrm{G}+\text { cocci } \\
2 \times \mathrm{G}+\text { rods } \\
2 \times \mathrm{G}+\text { rods } \\
(\text { coryneform) }\end{array}$ \\
\hline Luteal phase & 6 & $7-8$ & $\begin{array}{l}8(1 / 3) \\
\text { Five colony types }\end{array}$ & $\begin{array}{l}1 \times \mathrm{G}-\text { rods } \\
2 \times \mathrm{G}+\text { rods } \\
2 \times \text { yeast }\end{array}$ & $\begin{array}{l}1.67 \times 10^{3} \\
{\left[1.0 \times 10^{3}-2.6 \times 10^{3}\right]} \\
(3 / 3) \\
\text { Five colony types }\end{array}$ & $\begin{array}{l}1 \times \mathrm{G}-\text { rods } \\
1 \times \mathrm{G}+\text { rods } \\
1 \times \mathrm{G}+\text { cocci } \\
2 \times \text { yeast }\end{array}$ \\
\hline
\end{tabular}

The detection limits for bacterial isolation was 1000 microorganisms $\mathrm{g}^{-1}$. The numbers in parentheses for example $(0 / 3)$ indicate the number of animals from which microorganisms were isolated out of the total number sampled.

procedure allowed for calculation of the disector volumes for both epithelial and connective tissues.

The optical disector (Gundersen, 1986) was used to estimate the total number of mast cells in the epithelium and connective tissues of the vaginal cul-de-sac, and the total reference volume of the component tissues was estimated using the Cavalieri method (cited by Gundersen and Jensen, 1987). Cell density was then estimated as the number of mast cells in the component reference volume (epithelium or connective tissue), and expressed for all groups in terms of the number of mast cells that occupied a volume of vaginal cul-de-sac tissue of $10^{6} \mu \mathrm{m}^{3}$.

\section{Statistical analysis}

Data for vaginal cul-de-sac mass, epithelial and connective tissue volume, total number of cells and cell density were log transformed to overcome heterogeneity of variance and comparisons between groups made by ANOVA. The distribution of mast cells in the cul-de-sac tissue did not fit either a normal or a Poisson distribution. Consequently, statistical analysis of distribution of cells per disector volume was made by frequency distribution.

\section{Results}

\section{Microbial populations}

The numbers of microbial colonies isolated from luminal content and vaginal cul-de-sac tissue, and their Gram stain morphology, are summarized (Table 1). No lactobacilli were isolated from any of the groups of animals.

Juvenile animals. Gram staining of the smear samples from luminal contents revealed mucus and epithelial cells. No evidence of any associated bacteria was found in luminal content smears, but small numbers of Grampositive cocci, most likely to be enterococci, were isolated from the tissue samples.

Lactationally anoestrous group. One of the three luminal content samples had associated bacteria. After culture these were identified as Gram-positive cocci and Gram-positive rods, and a few Gram-negative rods were also present. The largest number of bacteria $\left(2.79 \times 10^{5} \mathrm{~g}^{-1}\right)$ was cultured from the vaginal cul-de-sac tissue of this group (Table 1). 
Table 2. Mean ( \pm SEM) mass and volume of the vaginal cul-de-sac of juvenile or adult female brushtail possums (Trichosurus vulpecula) that were either lactationally anoestrous or in the follicular or luteal phase of the oestrous cycle

\begin{tabular}{|c|c|c|c|c|}
\hline \multirow[b]{2}{*}{ Group } & \multirow[b]{2}{*}{$n$} & \multirow{2}{*}{$\begin{array}{l}\text { Vaginal cul-de-sac } \\
\text { mass (g) }\end{array}$} & \multicolumn{2}{|c|}{ Tissue volume $\left(\times 10^{11} \mu \mathrm{m}^{3}\right)$} \\
\hline & & & Epithelial tissue & Connective tissue \\
\hline Juvenile & 5 & $0.04 \pm 0.01^{\mathrm{a}}$ & $0.06 \pm 0.01^{\mathrm{a}}$ & $0.73 \pm 0.21^{\mathrm{a}}$ \\
\hline Lactationally anoestrous & 6 & $1.10 \pm 0.15^{b}$ & $1.63 \pm 0.93^{b}$ & $9.03 \pm 2.08^{b}$ \\
\hline Follicular & 6 & $11.00 \pm 2.10^{c}$ & $19.00 \pm 4.50^{c}$ & $35.60 \pm 3.5^{\mathrm{c}}$ \\
\hline Luteal & 6 & $2.67 \pm 0.26^{d}$ & $2.13 \pm 0.48^{b}$ & $12.30 \pm 2.50^{\text {be }}$ \\
\hline
\end{tabular}

Mean values within columns with different superscripts are significantly different $(P<0.001)$, except for c versus e $(P<0.01)$

Follicular phase. Luminal content samples from two of the three animals contained a few bacteria, and extensive dense fibrous material was present. Small numbers of bacteria were isolated from the tissue of this group, but a variety of bacterial colony types (9) was isolated, compared with that seen in other groups. Gram stain examination of the isolated colonies identified predominantly Grampositive organisms, both rods and cocci. However, only two types of colony were isolated from the luminal contents (Table 1).

Luteal phase. Mucus-polysaccharide, which stained non-specifically, was evident in the smear samples and in one animal some epithelial cells were associated with coryneform Gram-positive rods. Yeast cells were also seen in smears from two of the animals. Culture of vaginal culde-sac tissue resulted in the isolation of five types of colony - Gram-positive rods, Gram-negative rods and Gram-positive cocci. Two types of colony of yeast were cultured from the luminal swabs of one animal (Table 1).

With the exception of two of six animals in the follicular phase, the $\mathrm{pH}$ of luminal contents from all the groups ranged from 7 to 8 (Table 1). There were more bacterial colony types isolated from the follicular phase group than from the other groups.

\section{Tissue Gram stain sections}

Few bacteria were observed associated with the tissue surface. There was no evidence of bacterial invasion into the epithelial cell layer.

\section{Vaginal cul-de-sac mass and volume}

The mean mass of the vaginal cul-de-sac of juvenile brushtail possums was significantly lower $(P<0.001)$ than that of adult possums (Table 2). For adult females, the mean cul-de-sac mass was greatest $(P<0.001)$ in the follicular phase, and the luteal phase was significantly greater $(P<0.001)$ than that in lactating animals. These differences were complemented by differences in vaginal cul-de-sac volume (Table 2), although total cul-de-sac volume in lactationally anoestrous animals was not significantly different from that in luteal phase brushtail possums. The ratio of epithelial:connective tissue in adult brushtail possums was significantly different between follicular phase brushtail possums and lactationally anoestrous or luteal phase possums for both epithelial volume $(P<0.001)$ and connective tissue volume $(P<0.001)$, with $(P<0.01)$ for luteal phase.

\section{Number and density of mast cells}

The mean number and the mean density of mast cells for both epithelial and connective tissues of the vaginal cul-de-

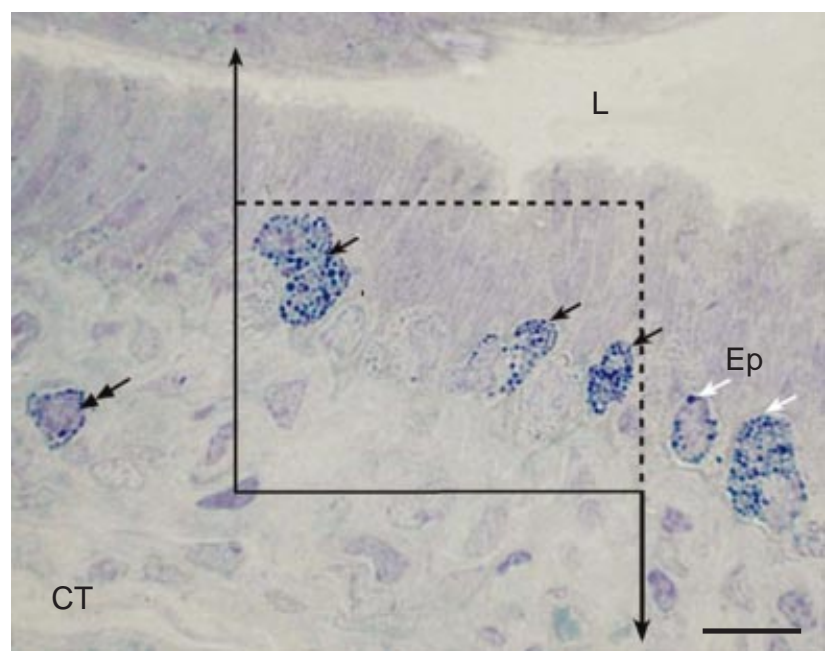

Fig. 1. The unbiased counting frame covers both epithelial (Ep) and connective tissue (CT) of the vaginal cul-de-sac of the brushtail possum (Trichosurus vulpecula) in the luteal phase of the oestrous cycle. The counting frame has inclusions lines (--------) and exclusion lines (-). Mast cell nuclei that are captured within the frame or nuclei that transect the inclusion line but not the exclusion line are counted. An aggregation of mast cells (single black arrow) is captured by the counting frame. A connective tissue mast cell (double black arrows) and two other epithelial mast cells (single white arrow) are also visible (magnification $\times 600$ ). L: lumen. Scale bar represents $13 \mu \mathrm{m}$. 
Table 3. Mean ( \pm SEM) numbers and densities of mast cells in epithelial and connective tissues of the vaginal cul-de-sac of juvenile or adult female brushtail possums (Trichosurus vulpecula) that were either lactationally anoestrous or in the follicular or luteal phase of the oestrous cycle

\begin{tabular}{lcccccc}
\hline & \multicolumn{2}{c}{$\begin{array}{c}\text { Number of mast cells } \\
\left(\times 10^{6}\right)\end{array}$} & & \multicolumn{2}{c}{$\begin{array}{c}\text { Density of mast cells } \\
\left(\text { cells per } 10^{6} \mu \mathrm{m}^{3}\right)\end{array}$} \\
\cline { 3 - 4 } \cline { 6 - 7 } Group & $n$ & $\begin{array}{c}\text { Epithelial tissue } \\
(P<0.01)\end{array}$ & $\begin{array}{c}\text { Connective tissue } \\
(P<0.01)\end{array}$ & & $\begin{array}{c}\text { Epithelial tissue } \\
(P<0.01)\end{array}$ & $\begin{array}{c}\text { Connective tissue } \\
(P<0.05)\end{array}$ \\
\hline Juvenile & 5 & $0.06 \pm 0.02^{\mathrm{a}}$ & $0.33 \pm 0.09^{\mathrm{a}}$ & & $14.88 \pm 5.17^{\mathrm{ab}}$ & $4.65 \pm 0.36^{\mathrm{ab}}$ \\
Lactationally anoestrous & 6 & $3.37 \pm 1.53^{\mathrm{b}}$ & $9.07 \pm 3.40^{\mathrm{b}}$ & & $37.86 \pm 12.13^{\mathrm{a}}$ & $9.11 \pm 1.67^{\mathrm{a}}$ \\
Follicular phase & 6 & $10.70 \pm 6.70^{\mathrm{b}}$ & $13.13 \pm 3.83^{\mathrm{b}}$ & & $4.21 \pm 2.10^{\mathrm{b}}$ & $3.63 \pm 1.16^{\mathrm{b}}$ \\
Luteal phase & 6 & $4.61 \pm 2.06^{\mathrm{b}}$ & $8.90 \pm 2.9^{\mathrm{b}}$ & & $21.38 \pm 8.03^{\mathrm{ab}}$ & $6.80 \pm 1.91^{\mathrm{ab}}$ \\
\hline
\end{tabular}

abMean values within columns with different superscripts are significantly different.

Table 4. Frequency distribution of mast cells (number of cells per disector) in epithelial and connective tissue of the vaginal cul-de-sac from juvenile or adult female brushtail possums (Trichosurus vulpecula) that were either lactationally anoestrous or in the follicular or luteal phase of the oestrous cycle

\begin{tabular}{|c|c|c|c|c|c|c|c|c|c|c|}
\hline \multirow[b]{3}{*}{ Group } & \multirow[b]{3}{*}{$n$} & \multirow[b]{3}{*}{ Total $^{\mathrm{a}}$} & \multicolumn{8}{|c|}{ Frequency distribution } \\
\hline & & & \multicolumn{4}{|c|}{ Epithelial tissue } & \multicolumn{4}{|c|}{ Connective tissue } \\
\hline & & & 0 cells & 1 cell & 2 cells & $\geqslant 3$ cells & 0 cells & 1 cell & 2 cells & $\geqslant 3$ cells \\
\hline Juvenile & 5 & 4630 & 317 & 64 & 26 & 14 & 3649 & 387 & 137 & 36 \\
\hline Lactationally anoestrous & 6 & 7275 & 786 & 240 & 203 & 130 & 4782 & 649 & 295 & 190 \\
\hline Follicular phase & 6 & 9800 & 2915 & 229 & 139 & 52 & 5900 & 431 & 103 & 31 \\
\hline Luteal phase & 6 & 7512 & 1115 & 127 & 136 & 145 & 5151 & 554 & 191 & 93 \\
\hline
\end{tabular}

aThe total number of disectors viewed.

sac are summarized (Table 3). The total number of mast cells in epithelial and connective tissues of the vaginal culde-sac was significantly lower $(P<0.01)$ in juvenile than in adult brushtail possums. However, neither the total number of mast cells nor location of the cells was significantly different between the stage of the oestrous cycle in adults, and the total numbers of cells were $12.44 \pm 4.83 \times 10^{6}$, $23.80 \pm 8.40 \times 10^{6}$ and $13.51 \pm 4.80 \times 10^{6}$ for lactationally anoestrous, follicular phase and luteal phase animals, respectively.

Mast cell density, that is the number of cells per $10^{6} \mu \mathrm{m}^{3}$, was not significantly different between juvenile and adult brushtail possums for either epithelial or connective tissues. In the follicular phase of the oestrous cycle, there were significantly fewer mast cells per $10^{6} \mu \mathrm{m}^{3}$ in both epithelial $(P<0.01)$ and connective tissues $(P<0.05)$ than in the other adult reproductive states.

The frequency distribution of mast cells (number of mast cells observed per disector) is shown (Table 4). Most optical disector frames failed to detect a mast cell. In the frames that did, there were instances in all groups in which more than three cells per disector were detected (Fig. 1) and these were regarded as mast cell aggregations. Analysis of the frequency distribution of mast cells per disector in the epithelium or connective tissues showed no significant differences among groups.

In all groups of animals, there were some instances in which mast cells had a degranulated appearance (for example, see Fig. 2) and others in which a cell shell containing a nucleus and clear cytoplasm was also observed. No stereological count was undertaken of these types of cell.

\section{Discussion}

To our knowledge, this study is the first attempt to determine microflora populations in the vaginal cul-de-sac of female brushtail possums or in any other marsupial species. No bacteria were isolated from the luminal contents of the vaginal cul-de-sac in 8 of 12 animals; and in those animals from which bacteria were isolated, there were very few $\left(<5 \times 10^{5} \mathrm{~g}^{-1}\right)$ microorganisms present compared with populations typically recorded in the gastrointestinal tract (Mackie, 1999). Even with the more robust method of determining microorganisms by plating tissue homogenates, surprisingly few bacteria $\left(\leqslant 4.7 \times 10^{5} \mathrm{~g}^{-1}\right)$ were isolated, although this method did isolate bacteria in 10 of 11 animals. Examination of Gram-stained tissue 


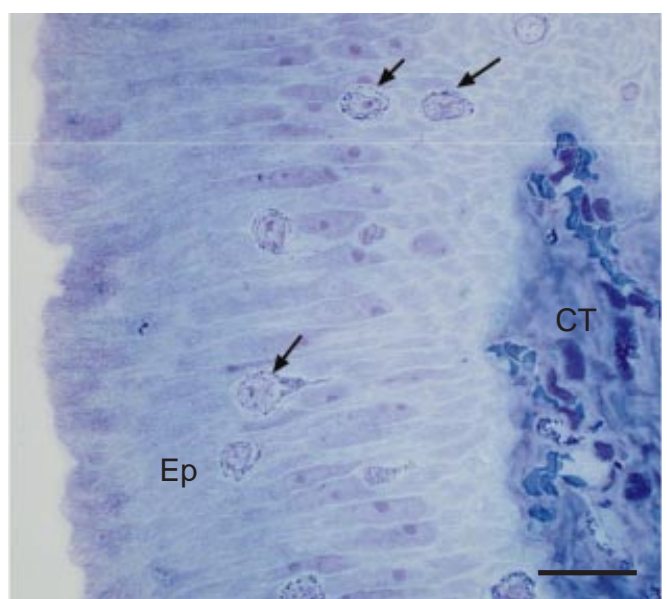

Fig. 2. Mast cells (black arrows) that may be degranulating are shown in the epithelial tissue (Ep) of the vaginal cul-de-sac of the brushtail possum (Trichosurus vulpecula) during the follicular phase of the oestrous cycle. Areas of clear unstained cytoplasm are apparent (magnification $\times 500$ ). CT: connective tissue. Scale bar represents $22 \mu \mathrm{m}$.

sections showed few bacterial cells. When smears made from swabs taken from the lumen of the vaginal cul-de-sac or from tissue homogenates were examined, some scattered clumps of Gram-positive cocci or rods or both were visible. This finding is reflected in the small numbers of bacterial types that could be cultured from this tissue. However, the types of organism cultured were similar to those observed under the microscope and it is also possible that some of the organisms viewed on the slides could not be cultured, but it appears that the resident normal microflora of the brushtail possum is small in comparison with that of humans. All bacteria isolated could be grown aerobically, and some were facultative anaerobes.

Studies of microflora populations in vaginal secretions from eutherian mammals typically identify much larger numbers of bacteria. For example, the normal microflora population of vaginal secretions from the human population is $10^{7}-10^{9}$ bacteria $\mathrm{g}^{-1}$, from which usually $13-15$ types of microorganism can be identified (Tannock, 1999).

It has been reported for eutherian mammals that there are changes in microflora populations in the female reproductive tract throughout the oestrous cycle, and the numbers of bacteria are significantly higher at the time of oestrus in the vagina and uterus of bitches (Baba et al., 1983) and in the vagina of rats (Larsen et al., 1976b). The microflora identified in these studies included streptococci, staphylococci and Escherichia coli, which predominated in the vagina but were also found in uterine samples (Baba et al., 1983). It was suggested that these bacterial colonies were of fecal origin, although this has yet to be confirmed (Baba et al., 1983). In the present study, bacteria isolated from the vaginal cul-de-sac of the brushtail possum have not been identified, but have been stored pending further analysis. It should be noted that the anatomy of the vaginal cul-de-sac of brushtail possums is markedly different from that of non-marsupials and this alone may account for the smaller numbers of bacteria associated with the brushtail possum vaginal cul-de-sac compared with the vaginal microflora of non-marsupials (for example humans, dogs and rats). It is well documented in humans, monkeys and mice that a microflora inhabits all body sites that are exposed to the external environment. The unique function of these sites is that they provide conditions that favour the establishment of some species (Tannock, 1995). The fact that the vaginal tract of the brushtail possum is not exposed to the environment in the same way as in non-marsupials may influence the numbers and types of organisms inhabiting this area.

It is known that most bacterial colonies grow best at a neutral pH (Brock and Madigan, 1991). In the present study, $\mathrm{pH}$ values for the luminal contents of the vaginal cul-de-sac of the brushtail possum ranged from four to eight. The smallest numbers of bacteria were isolated from animals in the luteal phase of the oestrous cycle, when $\mathrm{pH}$ values ranged from five to seven, and the highest numbers were isolated in the lactationally anoestrous group (pH 7-8).

The application of the optical disector in conjunction with an unbiased counting frame, and small $x, y$ step size used in this study, allowed for a systematic analysis with large coverage of vaginal cul-de-sac tissue. This approach minimized the possible bias from the anisotrophic nature of the mast cell distribution within the tissue, and maximized the chance of cells being selected by the optical disector counting frame. A consequence of adopting this method was that a large number of disectors was used, and most had a zero count (no mast cells present). Most cells were located in luminal epithelial tissue or in the region of the connective tissue that was close to the epithelial-connective tissue boundary. The appearance of mast cell aggregations (that is $>3$ cells per disector) within the epithelium or at the epithelial-connective tissue border indicates that the action of these cells may be directed towards the epithelium or the lumen. The aggregation of mast cells associated with inflammatory and immunological mechanisms is known to be a response to a chemotaxic stimulus (Conti et al., 1995). As aggregations of mast cells in the vaginal cul-de-sac tissues appear to be unrelated to pathogenic stimulus, the initiation of cell aggregation may be via a diffusive source, such as increasing hormonal concentrations, rather than from microorganisms. Studies in rats indicate that mast cell products, such as histamine (Ferrando and Nalbandov, 1968) and heparin (Nakamura et al., 1987) are involved in cellular mechanisms, and some of these involve the microvasculature. Hypertrophy of vaginal cul-de-sac tissue during the follicular phase of the oestrous cycle is initiated and regulated by cellular mechanisms. It is possible that mast cell products are involved in this vaginal cul-de-sac response, but this has yet to be determined. During the 
oestrous cycle, the greatest change in vaginal cul-de-sac volume was seen in the follicular phase and there was a trend for the total number of mast cells to increase at this time, although this was not statistically significant. Changes in the number of mast cells with reproductive status could have been masked by the wide variation in mast cell populations among animals, by the small sample size ( $n=5-6$ animals per group) or by the anisotrophic nature of the mast cell distribution. It is possible that a major role of mast cells in the vaginal cul-de-sac tissue is to control pathogenic invasion and that the very small numbers of microorganisms observed in the present study reflects the success of this immunological defence mechanism. There were significantly fewer mast cells in both epithelial and connective tissues of the vaginal cul-de-sac from juvenile than from adult possums. However, this finding may simply reflect the large differences in mass of the reproductive tract between juvenile and adult possums, rather than differences in reproductive status.

The analyses of mast cell density identified changes between groups that may be relevant to tissue function. Density of mast cells among the adult female groups was significantly greater in lactational anoestrus than in the follicular phase, for both epithelial and connective tissue components. Surprisingly, mast cell density in juvenile brushtail possums was not significantly different from that in adult brushtail possums, despite the differences in the number of mast cells. Again, this finding may simply be attributed to small sample size, but it could indicate some pro-active mechanism of mast cell activation, whereby the cells are held in physiological diapause until required.

The decrease in density of mast cells in epithelial tissue and connective tissues during the follicular phase of the oestrous cycle when circulating oestrogen concentrations are high is consistent with earlier reports on mast cell degranulation (Gibbons and Chang, 1972). Krishna and Terranova (1985) and Nakamura et al. (1987) both postulated that a primary action of the preovulatory LH surge, which is induced by increasing oestrogen concentrations, was to stimulate mast cell degranulation which in turn releases histamine. Histamine has been identified in mast cell granules (Nakamura et al., 1987; Krishna et al., 1989) and it has known vasodilatory effects (Brock and Madigan, 1991). It is not yet known whether mast cells in the vaginal cul-de-sac tissue of brushtail possums release histamine, but studies in other marsupial species have identified very high concentrations of histamine of mast cell origin. Histamine (Haynes, 1991) and heparin (Santos and Machado, 1994) have been identified in the mast cells of lymph nodes of some marsupials. The classical role of histamine is that of a chemical mediator in tissue, acting as a vasodilator of blood vessels, and stimulating contraction in smooth muscle, accompanied by copious mucus production (Brock and Madigan, 1991). It is possible that the decreasing density of mast cells in epithelial tissue during the follicular phase is due to cell degranulation and the release of histamine, which causes the increased mucus production by the epithelial cells that occurs at this time (Crawford et al., 1999). Heparin is known to act as a suppressor of immune cell development (Frieri and Metcalfe, 1983) and to prevent or initiate hormone release (Jacques, 1980). A potential role for heparin in mast cells in the brushtail possum vaginal cul-de-sac is unclear, but the association with histamine may be one of synergy to optimize the oestrogenic influence on such mechanisms as cell growth and proliferation (Gunin and Sharov, 1998). Mast cells have been found to interact with connective tissue components through both immunological and nonimmunological actions, whereby heparin and proteases from degranulated mast cells provide nutrients and influence fibroblast activity (Atkins et al., 1985). The decrease in mast cell density in connective tissue during the follicular phase of the oestrous cycle again may be indicative of the degranulation process, with heparin and histamine acting as the chemical mediators within connective and epithelial tissues. However, if the decrease in mast cell density during the follicular phase is due to an increase in the rate of degranulation, then it would be expected that large numbers of fully or partially degranulated mast cells would be observed in the tissue. Identification of fully and partially degranulated cells would not always be identifiable under a light microscope.

The role of mast cells in biological tissues is emerging as ubiquitous. Féger et al. (2002) discuss a role for mast cells in the direct phagocytosis of bacteria in some conditions and also recruitment of other immune cells. If the mast cells in the vaginal cul-de-sac tissues respond to pathogenic infiltration it could be expected that there would be an increase in the total number of mast cells as the volume of tissue increased, but this did not occur. The Giemsa staining method has not identified any bacteria that may have been phagocytosed by mast cells and any evidence of organelle activity within the mast cell would be evident only under an electron microscopy investigation, as would the presence of other immune cells such as macrophages. However, the Giemsa staining method would identify any neutrophil recruitment and these cells were not observed in the present study.

The vaginal cul-de-sac is the conduit through which an immunologically challenged fetus journeys to the external environment (Tyndale-Biscoe and Janssens, 1988). Mast cells may be secreting protective substances into the lumen of vaginal cul-de-sac to provide protection for the fetus during development in the marsupium where the fetus is exposed to factors that activate immunological tissue, such as lymph nodes (Chiarini-Garcia and Pereira, 1999). Mast cells in lymphatic tissues of some marsupials have been purported to play specific roles in immunological responses (Haynes, 1991; Chiarini-Garcia and Machado, 1992; Chiarini-Garcia and Pereira, 1999; Chiarini-Garcia et al., 2000) and it may be that the mast cells in vaginal cul-de-sac are also part of an immunological defence mechanism.

In conclusion, the present study has shown that there are very small numbers of microorganisms present in the lumen 
of the vaginal cul-de-sac of brushtail possums. The mechanism by which the microorganisms are maintained at small numbers may be due to mast cell activity, but it seems more likely that mast cells play an important role in tissue function (Crawford et al., 1999). The anisotrophic nature of their spatial location and the significant changes to mast cell densities and possibly also in degranulation in the follicular phase of the oestrous cycle may be indicative of a role in the reproductive process.

This work was partially funded by a scholarship from the Todd Foundation. The authors thank P. D. Johnstone for statistical analysis and E. G. Thompson for assistance with animals.

\section{References}

Abraham SN and Malaviya R (1997) Mast cells in infection and immunity Infection and Immunity $\mathbf{6 5}$ 3501-3508

Atkins FM, Friedman MM, Subba Rao PV and Metcalfe DD (1985) Interactions between mast cells, fibroblasts and connective tissue components International Archives of Allergy and Applied Immunology 77 96-102

Baba E, Hata H, Fukata T and Arakawa A (1983) Vaginal and uterine microflora of adult dogs American Journal of Veterinary Research $\mathbf{4 4}$ 606-609

Bancroft JD and Stevens A (1990) Theory and Practice of Histological Techniques 3rd Edn. Churchill Livingstone, Edinburgh; New York

Brock TD and Madigan MT (1991) Biology of Microorganisms 6th Edn. Prentice Hall, Englewood Cliffs, NJ

Cavalieri B (1635) Geometria Indivisibilibus Continuorum Typis Clemetis Feronij Bononi

Chiarini-Garcia H and Machado CRS (1992) Mast cell types in the lymph nodes of the opossum Didelphis albiventris (Marsupialia, Didelphidae) Cell and Tissue Research 268 571-574

Chiarini-Garcia H and Pereira FM (1999) A comparative study of lymph node mast cell populations in five marsupial species Tissue and Cell 31 318-326

Chiarini-Garcia H, Santos AAD and Machado CRS (2000) Mast cell types and cell-to-cell interactions in lymph nodes of the opossum Didelphis albiventris. Anatomy and Embryology 201 197-206

Conti P, Boucher W, Letourneau R, Feliciani C, Reale M, Barbacane RC, Vlagopoulos P, Bruneau G, Thibault J and Theoharides TC (1995) Monocyte chemotactic protein-1 provokes mast cell aggregation and [3H]5HT release Immunology $\mathbf{8 6} 434-440$

Crawford JL, Shackell GH, Thompson EG, McLeod BJ and Hurst PR (1997) Preovulatory follicle development and ovulation in the brushtail possum (Trichosurus vulpecula) monitored by repeated laparoscopy Journal of Reproduction and Fertility $110361-370$

Crawford JL, McLeod BJ, Thompson EG and Hurst PR (1998) Presence of males affects the incidence of ovulation after pouch young removal in brushtail possums (Trichosurus vulpecula) Animal Reproduction Science 51 45-55

Crawford JL, McLeod BJ and Hurst PR (1999) Cyclical changes in epithelial cells of the vaginal cul-de-sac of brushtail possums (Trichosurus vulpecula) Anatomical Record 254 307-321

Féger F, Varadaradjalou S, Gao Z, Abraham SN and Arock M (2002) The role of mast cells in host defense and their subversion by bacterial pathogens Trends in Immunology 23 151-158

Ferrando G and Nalbandov AV (1968) Relative importance of histamine and estrogen on implantation in rats Endocrinology 83 933-937

Frieri M and Metcalfe DD (1983) Analysis of the effect of mast cell granules on lymphocyte blastogenesis in the absence and presence of mitogens: identification of heparin as a granule-associated suppressor factor Journal of Immunology 131 1942-1948
Galli SJ (1993) New concepts about the mast cell New England Journal of Medicine 328 257-265

Garfield RE, Bytautiene E, Vedernikov YP, Marshall JS and Romero R (2000) Modulation of rat uterine contractility by mast cells and their mediators American Journal of Obstetrics and Gynecology 183 $118-125$

Gibbons AF and Chang MC (1972) Number of mast cells in the rat uterus with special reference to its relation to hormonal treatment and decidual response Biology of Reproduction 6 193-203

Gundersen HJG (1977) Notes on the estimation of the numerical density of arbitrary profiles: the edge effect Journal of Microscopy $\mathbf{1 1 1}$ 219-223

Gundersen HJG (1986) Stereology of arbitrary particles. A review of unbiased number and size estimators and the presentation of some new ones, in memory of William R. Thompson Journal of Microscopy 143 3-45

Gundersen HJG and Jensen EB (1987) The efficiency of systematic sampling in stereology and its prediction Journal of Microscopy 147 229-263

Gundersen HJG, Bagger P, Bendtsen TF et al. (1988) The new stereological tools: disector, fractionator, nucleator and point sampled intercepts and their use in pathological research and diagnosis APMIS 96 857-881

Gunin AG and Sharov AA (1998) Role of mast cells in oestradiol effects on the uterus of ovariectomized rats Journal of Reproduction and Fertility $11361-68$

Haynes JI (1991) Cervical lymph nodes and mast cells in the marsupial Sminthopsis crassicaudata. Anatomical Record 231 7-13

Howard CV and Reed MG (1998) Unbiased Stereology: Three-dimensional Measurement in Microscopy. Bios Scientific, Oxford, UK

Jacques LB (1980) Heparins - anionic polyelectrolyte drugs Pharmalogical Reviews 31 99-166

Jones RE, Duvall D and Guillette LJ (1980) Rat ovarian mast cells: distribution and cyclic changes Anatomical Record 197 489-493

Jones RE, Duvall D, Guillette LJ and Lopez KH (1994) Number and state of rat ovarian mast cells after exogenous administration of luteinizing hormone Comparative Biochemistry and Physiology 108 555-559

Kean RI, Marryatt RG and Carroll ALK (1964) The female urogenital system of Trichosurus vulpecula (marsupialia) Australian Journal of Zoology 12 $18-41$

Krishna A and Terranova PF (1985) Alterations in mast cell degranulation and ovarian histamine in the proestrous hamster Biology of Reproduction 32 1211-1217

Krishna A, Terranova PF, Matteri RL and Papkoff H (1986) Histamine and increased ovarian blood flow mediate $\mathrm{LH}$-induced superovulation in the cyclic hamster Journal of Reproduction and Fertility $\mathbf{7 6} 23-29$

Krishna A, Beesley K and Terranova PF (1989) Histamine, mast cells and ovarian function Journal of Endocrinology 120 63-71

Larsen B, Markovetz AJ and Galask RP (1976) Quantitative alterations in the genital microflora of female rats in relation to the estrous cycle Journal of Infectious Diseases 134 486-489

Lyne AG and Verhagen AMW (1957) Growth of the marsupial Trichosurus vulpecula and a comparison with some higher animals Growth 21 167-195

McLeod BJ, Thompson EG, Crawford JL and Shackell GH (1997) Successful group housing of wild-caught brushtail possums (Trichosurus vulpecula) Animal Welfare 6 67-76

Mackie RI (1999) Developmental microbial ecology of the neonatal gastrointestinal tract American Journal of Clinical Nutrition 69 1035S-1045S

Mahoney PM, Hurst PR, McLeod BJ and McConnell MA (2001a) Are mast cells important for reproductive function in the Brushtail possum? Reproduction Abstract Series 27 Abstract 18

Malaviya R, Twesten NJ, Ross EA, Abraham SN and Pfeifer JD (1996) Mast cells process bacterial Ags through a phagocytic route for class I MHC presentation to T cells Journal of Immunology 56 1490-1496

Mori A, Zhai YI, Toki T, Nikaido T and Fujii S (1997) Distribution and heterogeneity of mast cells in the human uterus Human Reproduction $12368-372$

Nakamura Y, Smith M, Krishna A and Terranova PF (1987) Increased number of mast cells in the dominant follicle of the cow: relationships 
among luteal, stromal and hilar regions Biology of Reproduction 37 546-549

Pilton PE and Sharman GB (1962) Reproduction in the marsupial (Trichosurus vulpecula) Journal of Endocrinology 25 119-136

Santos AA and Machado CR (1994) Histochemical and ultrastructural studies of mast cells in the intestinal mucosa and skin of the opossum Didelphis albiventris. Histochemical Journal 26 233-238

Sterio DC (1984) The unbiased estimation of number and sizes of arbitrary particles using the disector Journal of Microscopy 134 27-36

Tannock GW (1995) Normal Microflora: An Introduction to Microbes Inhabiting the Human Body Chapman and Hall, London

Tannock GW (1999) Medical Importance of the Normal Microflora Kluwer, Dordrecht; Boston

Tyndale-Biscoe CH (1955) Observations on the reproduction and ecology of the brushtailed possum Trichosurus vulpecula. Australian Journal of Zoology 3 162-185

Tyndale-Biscoe CH and Janssens P (1988) The Developing Marsupial. Models for Biomedical Research Springer-Verlag, Berlin, Heidelberg

Wilhelm M, King B, Silverman A-J and Silver R (2000) Gonadal steroids regulate the number and activational state of mast cells in the medial habenula Endocrinology 141 1178-1186

Received 3 April 2002.

First decision 17 May 2002.

Revised manuscript received 11 June 2002.

Accepted 13 June 2002. 